\title{
REORIENTASI MANAJEMEN PEMBELAJARAN PENDIDIKAN AGAMA ISLAM (PAI) DAN DERADIKALISASI AGAMA
}

\author{
Fatah Syukur \\ Universitas Islam Negeri (UIN) Walisongo Semarang \\ e-mail: fsyukur68@gmail.com
}

\begin{abstract}
Islamic religious education in schools substantively had a very important role. In accordance with the mandate of the Law on National Education System, religious education should be provided to learners at all levels of education. Religious education was expected not only to provide knowledge of religion, but also build the personality character of the students using religious values taught. Through quantitative research, this study examined the implementation of Islamic religious education in schools with the research problems: is there any correlation with religious observance, and any other factors that affect the behavior of religion? How does the orientation of Islamic religious educationin schools? The results showed that Islamic education is not positively correlated to the level of religious observance. Similarly, differences in men and women are not correlated to the level of religious observance. Therefore, there will be necessary reorientation of religious education in schools.

Pendidikan agama Islam di sekolah secara substantif memiliki peran yang sangat penting. Sesuai dengan amanat Undang-undang Sistem Pendidikan Nasional, bahwa Pendidikan Agama harus diberikan kepada peserta didik di semua jenjang pendidikan. Diharapkan Pendidikan Agama bukan hanya memberikan pengetahuan agama saja, akan tetapi juga membentuk karakter kepribadian anak didik dengan nilai-nilai yang diajarkan oleh agama. Melalui penelitian kuantitatif, tulisan ini mengkaji pelaksanaan Pendidikan Agama Islam di sekolah, apakah ada korelasinya dengan ketaatan beragama, adakah faktor-faktor lain yang berpengaruh terhadap perilaku beragama? Serta Bagaimana orientasi Pendidikan Agama Islam di sekolah?. Hasil penelitian ini menunjukkan bahwa Pendidikan Agama Islam tidak berkorelasi positif terhadap tingkat ketaatan beragama. Demikian pula perbedaan laki-laki dan perempuan tidak berkorelasi terhadap tingkat ketaatan beragama. Oleh karena itu, maka perlu ada reorientasi Pendidikan Agama di sekolah.
\end{abstract}

Keywords: Pendidikan Agama Islam, sekolah, reorientasi, deradikalisasi 


\section{A. Pendahuluan}

Dengan maraknya pemberitaan tentang berbagai paham dan gerakan fundamentalis dan eksklusifisme pemahaman ajaran Islam, menarik untuk mencermati wilayah Pendidikan Agama Islam di sekolah. Keberadaan Pendidikan Agama Islam di sekolah merupakan muatan kurikulum yang wajib diberikan di setiap jenjang pendidikan mulai dari SD, SMP dan SMA/SMK. Bahkan di sekolahsekolah yang berbasis keagamaan non-Islam pun wajib memberikan Pendidikan Agama Islam, apabila ada siswanya yang beragama Islam. Bagaimana konsep Pendidikan Agama yang diajarkan di sekolah? Apakah Pendidikan Agama di sekolah hanya formalitas yang menekankan pada faktor kognitif saja.

Efektivitas Pendidikan Agama Islam di SMA diukur dengan indikator terbentuknya siswa sebagai Muslim yang taat beragama. Konsep ini melahirkan asumsi bahwa Pendidikan Agama di sekolah berhubungan dengan ketaatan beragama. Dalam kerangka pengembangan Pendidikan Agama yang efektif, hubungan Pendidikan Agama dan ketaatan beragama perlu dan relevan untuk ditelaah.

Pendidikan Agama merupakan variabel kehidupan beragama yang sangat asasi dalam proses pembentukan sikap dan perilaku anak, khususnya perilaku agama yang disebut ketaatan beragama. Banyak penelitian yang menunjukkan peran pendidikan dalam pembentukan perilaku individu (siswa). Menurut Argyle sebagaimana dikutip oleh Wirawan Sarwono dan Harry Susanto, ${ }^{1}$ menyimpulkan bahwa tingkah laku individu tergantung pada corak disiplin (dalam arti training) yang diberikan kepadanya dalam sosialisasi. Whiting juga menemukan bahwa pendidikan berpengaruh besar terhadap sikap dan perilaku individu.

Temuan-temuan tersebut mengindikasikan adanya hubungan yang erat antara pendidikan dan perilaku siswa, dalam hal ini hubungan Pendidikan Agama dan ketaatan beragama atau perilaku agama siswa. Asumsi dasarnya adalah bahwa Pendidikan Agama melahirkan ketaatan beragama siswa. Siswa yang mencapai hasil Pendidikan Agama dengan baik di sekolah diasumsikan memiliki tingkat ketaatan beragama yang tinggi. Jadi Pendidikan Agama di sekolah berfungsi memprediksi ketaatan beragama siswa. Permasalahannya adalah, jika secara konsepsi ideal Pendidikan Agama memiliki hubungan erat

${ }^{1}$ Sarwono Wirawan dan Heri Susianti, "Upaya Penegakan Disiplin Nasional dalam Kerangka Nilainilai Sosial Budaya Indonesia; Suatu Analisis Psikososial," dalam Himpunan Prasaran dalam Seminar Polri, (Jakarta: PTIK, 1991), h. 270. 
dengan ketaatan beragama, maka apakah benar secara empirik dan terbukti secara realistik di SMA Negeri Semarang? Apakah siswa yang memiliki prestasi tinggi dalam Pendidikan Agama juga merefleksi dalam ketaatan beragamanya?

Pertanyaan-pertanyaan semacam ini sangat researchable, sehingga menarik perhatian penulis untuk dikaji. Dalam hal ini penulis mencoba mengangkat tema Pendidikan Agama dan Ketaatan Beragama, Siswa SMA Negeri Semarang. Pada dasarnya pokok permasalahan yang ingin diungkap dalam tulisan ini meliputi: fungsi Pendidikan Agama di SMA, dan variable yang berperan dalam proses pembentukan ketaatan beragama.

Kedua pokok permasalahan ini dirumuskan dalam pertanyaan-pertanyaan sebagai berikut: (1) Dalam konteks kehidupan sosial yang cenderung berubah ke arah materialistik, apakah Pendidikan Agama di SMA masih efektif mencapai hasil yang diharapkan? (2) Secara teoritik, hasil (output) Pendidikan Agama berhubungan positif dengan aktualisasi (outcome) Pendidikan Agama dalam ketaatan beragama. Apakah secara empirik Pendidikan Agama di SMA berhubungan dengan ketaatan beragama siswa? (3) Variable yang berperan terhadap proses pembentukan ketaatan beragama siswa bersifat kompleks. Apakah variable yang berpengaruh terhadap ketaatan beragama disamping Pendidikan Agama? (4) Apakah variable jenis kelamin berhubungan dengan ketaatan beragama siswa; apakah antara siswa laki-laki dan siswa perempuan terdapat perbedaan ketaatan beragama?

Dalam rangka menjawab permasalahan di atas, maka dalam populasi penelitian ini adalah siswa SMA Negeri Semarang. Namun karena luasnya populasi dan terbatasnya kemampuan penulis, maka penulis mengambil sampling 3 (tiga) SMA Negeri di Semarang, yakni SMA Negeri 6, SMA Negeri 1 dan SMA Negeri 8. Pengambilan sampling ini menggambarkan representasi sebagai sekolah yang berada di tengah kota dan di pinggir kota. Dari setiap sekolah akan diambil $10 \%$ (dari yang beragama Islam) sebagai sampel. Pengambilan sampel dilakukan dengan teknik startified random sampling, sedangkan randomisasinya dilakukan dengan menggunakan tabel angka random.

Data pokok penelitian berupa hasil Pendidikan Agama dan ketaatan beragama serta lingkungan keagamaan siswa. Data tentang hasil Pendidikan Agama dilakukan dengan studi dokumen. Sedang data tentang ketataan beragama dan lingkungan keagamaan siswa diperoleh melalui angket. Data sekunder yang relevan dikumpulkan dengan studi dokumen dan wawancara. 
Angket sebagai instrumen pengumpul data primer, sebelum dioperasikan diuji secara teoritik dan empirik. Uji teoritik untuk mengetahui validitas isi dan konstruksi, sedang uji empirik untuk mengetahui reliabilitas dan validitas.

Penelitian ini bersifat kuantitatif, di mana data yang terkumpul dianalisis dengan statistik. Adapun teknik yang digunakan adalah: (1) Korelasi product moment, untuk mengukur hubungan Pendidikan Agama dengan ketaatan beragama, hubungahn lingkungan keagamaan dengan Pendidikan Agama, dan hubungan lingkungan keagamaan dengan ketaatan beragama. (2) Korelasi parsial untuk menguji peranan variable kontrol sehingga ditemukan variabel yang secara nyata berhubungan erat dengan ketaatan beragama. (3) Uji F untuk mengetahui signifikansi korelasi parsial, dan (4) Uji t (t-test) untuk membandingkan tingkat ketaatan beragama antara siswa laki-laki dan siswa perempuan.

\section{B. Manajemen Pendidikan Agama Islam}

Materi Pendidikan Agama merupakan bagian penting dalam kurikulum pendidikan nasional yang wajib diselenggarakan, di samping pendidikan Pancasila dan pendidikan kewarganegaraan. Pendidikan Agama (baca: Pendidikan Agama Islam) wajib diselenggarakan pada setiap jenjang pendidikan formal sesuai dengan agama yang dipeluk oleh peserta didik. Ini berarti bahwa kedudukan Pendidikan Agama sangat penting. Pentingnya Pendidikan Agama, bukan hanya karena isi atau materi Pendidikan Agama itu sendiri yang harus disampaikan kepada peserta didik, akan tetapi juga diharapkan dengan kehidupan beragama akan dapat terwujud secara terpadu antara dimensi kehidupan satu dengan yang lain secara utuh dalam setiap individu warga negara.

Pendidikan Agama tidak hanya sekadar menyampaikan ajaran agama kepada peserta didik, tetapi juga menamakan komitmen terhadap ajaran agama yang dipelajarinya. Ini jelas berbeda dengan materi pelajaran lain, yang hanya menekankan pada penguasaan materi semata-mata. Dalam Pendidikan Agama, aspek ilmu dan amal harus menyatu, keduanya-duanya harus berjalan seimbang. Sebagaimana penjelasan dalam Undang-undang tentang Sistem Pendidikan Nasional, Pendidikan Agama merupakan usaha untuk memperkuat iman dan ketaqwaan terhadap Tuhan Yang Maha Esa, sesuai dengan agama yang dianut oleh peserta didik yang bersangkutan dengan memperhatikan 
tuntutan untuk menghormati agama lain dalam hubungan kerukuman antar umat beragama dalam masyarakat untuk mewujudkan persatuan nasional.

Oleh karena itu Pendidikan Agama memerlukan pendekatan pengajaran yang berbeda dari pendekatan subjek pelajaran lain. Untuk menanamkan penguasaan materi dan juga menanamkan komitmen, maka metode yang dipergunakan dalam pengajaran pendidikan Agama harus mendapat perhatian yang seksama dari pendidik agama. Mengapa demikian? Karena metode sangat berarti atas keberhasilan suatu materi pelajaran. Metode tidak hanya berpengaruh pada peningkatan penguasaan materi tentang ajaran agama, tetapi juga pada pananaman komitmen beragama.

\section{Hubungan Pendidikan Agama dengan Ketataatan Beragama}

Konseptualiasi tentang hubungan Pendidikan Agama dengan ketaatan beragama didasarkan pada dua kerangka acuan, yaitu kerangkan acuan edukatif dan kerangka acuan psikologik.

\section{a. Kerangka Acuan Edukatif}

Secara makro, Pendidikan Agama di SMA merupakan sub-sistem dari program pengajaran di SMA. Namun secara mikro, Pendidikan Agama itu sendiri merupakan sistem. Sebagai suatu sistem, Pendidikan Agama memiliki berbagai unsur yang saling berhubungan dan berpengaruh, yang meliputi: masukan mentah (raw input), proses belajar mengajar (teaching-learning process), masukan instrumental (instrumental input), keluaran (output), dan aktualisasi keluaran (outcome).

Aktualisasi keluaran (outcome) Pendidikan Agama pada hakekatnya merupakan refleksi dari hasil Pendidikan Agama yang menifes dalam bentuk perilaku agama siswa yang disebut ketaatan beragama. Jadi, ketaatan beragama adalah produk Pendidikan Agama.Berdasarkan konsep tersebut dapat diasumsikan bahwa ketaatan beragama merupakan fungsi Pendidikan Agama. Dengan demikian, secara teoritik, Pendidikan Agama memiliki hubungan sistematik dengan ketaatan beragama (output pendidikan dengan outcome Pendidikan Agama). Secara skematik hubungan tersebut dapat digambarkan sebagai berikut: 


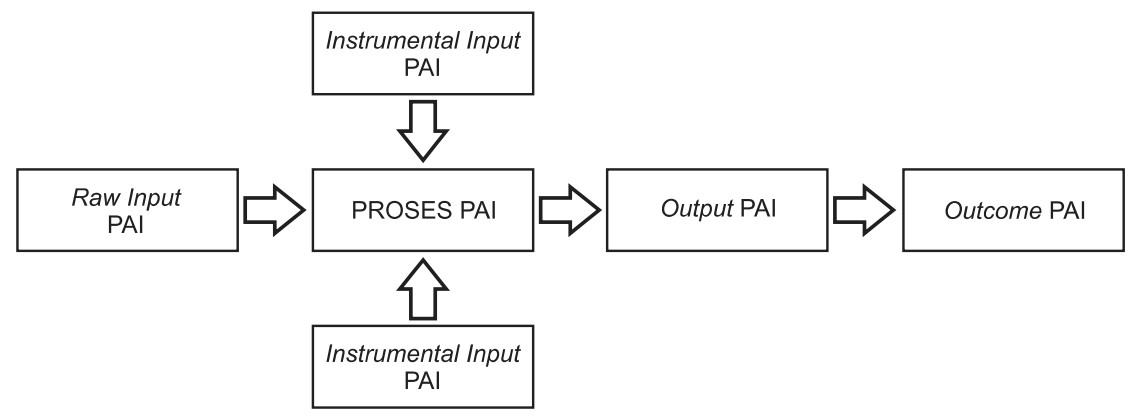

Skema 1.

Hubungan Sistematik Dalam Sistem Masukan-Keluaran Pendidikan Agama

\section{b. Kerangka Acuan Psikologik}

Proses Pendidikan Agama menimbulkan dua efek, yaitu efek pengajaran (instructional effect) dan efek pengiring (nurturant effect). Manifestasi dari efek pengajaran berupa penguasaan siswa terhadap pengetahuan agama (gnosis). Secara psikologik, gnosis tentang ajaran agama berhubungan dengan aktualisasi ajaran agama (praxis) melalui peristiwa-peristiwa psikologis yang merupakan mata rantai yang terdiri dari kognisi, afeksi, konasi, volisi, motivasi, dan praxis. ${ }^{2}$

Dalam konteks pendidikan, praxis merupakan aktualisasi dari ajaran agama yang disebut ketaatan beragama. Ketaatan beragama tidak lahir begitu saja, melainkan melalui suatu proses, yaitu berawal dari pengetahuan tentang agama (gnosis). Sedangkan gnosis adalah hasil dari Pendidikan Agama. Secara logis, hubungan tersebut dapat diformulasikan sebagai berikut: Pendidikan Agama melahirkan gnosis, dan gnosis melahirkan praxis. Jadi, Pendidikan Agama, secara psikologik, berfungsi memprediksi ketaatan beragama.

\section{Hubungan Ketaatan Beragama dengan Lingkungan}

Berbagai penelitian mengungkapkan peranan intervensi lingkungan terhadap pola perilaku siswa. Colemen (1966), mengungkapkan bahwa lingkungan lebih besar pengaruhnya dari pada sekolah. Hal ini senada dengan

\footnotetext{
2Mochtar Buchori, "Transformasi Tata Nilai", dalam Himpunan Prasarana dalam Seminar Polri, Oarkata: PTIK, 1991), h. 289.
} 
Mugihadi (1979) yang mengungkapkan adanya hubungan lingkungan sekolah dan keluarga dengan keberhasilan pendidikan. Pendapat ini perkuat pendapat Zakiah Daradjat, ${ }^{3}$ yang berkesimpulan bahwa terbentuknya ketaatan beragama banyak dipengaruhi oleh lingkungan keluarga. Dari konsep tersebut, dapat dirumuskan suatu asumsi bahwa ketaatan beragama dipengaruhi oleh lingkungan, dalam hal ini adalah lingkungan keagamaan, baik dalam keluarga, sekolah maupun masyarakat.

\section{Perbedaan Ketaatan Beragama}

Secara psikologis wanita sering diperlakukan sebagai lebih emosional, lebih pasif, dan lebh submisif. ${ }^{4}$ Chudorow dengan teorinya yang disebut "mothering" (keibuan), menyatakan bahwa unsur psikologis internal pada diri perempuan yang membuatnya secara sukarela melestarikan kepercayaan masyarakat tentang peranan perempuan dan menerima kekurangan. Hal ini terjadi pada perempuan dan tidak pada laki-laki, karena perempuan memiliki keterkaitan dengan aktivitas keibuan, sedang laki-laki tidak. ${ }^{5}$ Al-Qur'an secara normatif tidak membedakan antara laki-laki dan perempuan, tetapi dalam konteks tertentu diakui bahwa laki-laki memiliki kelebihan atas perempuan. ${ }^{6}$

Secara sosiologis, berbagai masyarakat dalam sejarahnya selalu muncul stereotip yang menganggap perempuan berbeda dengan laki-laki. Implikasi stereotip tersebut ialah berupa perbedaan pola asuh dan perlakuan orang tua terhadap anak laki-laki dan perempuan. Stereotip masyarakat dan sikap serta perlakuan orang tua yang membedakan laki-laki dan perempuan ternyata berpengaruh terhadap sikap dan perilaku anak itu sendiri. Terbentuknya ketaatan beragama sebagai salah satu bentuk tingkah laku, yaitu tingkah laku beragama tentu tidak dapat lepas dari pengaruh nilai-nilai yang berlaku dalam masyarakat. Dalam hal ini, ${ }^{7}$ mengemukakan adanya hubungan antara nilai-nilai sosial dengan corak sikap dan pola tingkah laku. Nilai yang berlaku dalam masyarakat kita pada umumnya tetap mempertahankan perbedaan antara laki-

\footnotetext{
3Zakiah Daradjat, Pendidikan dalam Keluarga dan Sekolah, (Jakarta: Rohana, 1993), h. 64.

${ }^{4}$ Arif Budiman, Pembagian Kerja Secara Seksual: Sebuah Pembahasan Sosiologis tentang Peran Wanita di dalam Masyarakat, (Jakarta: Gramedia, 1985), h. 1.

${ }^{5}$ Gadis, Ariviva, "Feminisme Pasca Modernis", Jurnal Prisma, No. 1, 1993, h. 34.

${ }^{6} \mathrm{QS}$. al-Nisa' [4]: 32.

${ }^{7}$ Alfian, Transformasi Sosial Budaya dalam Pembangunan Nasional, (Jakarta: UI Pres,1985), h. 156.
} 
laki dan perempuan. Akibatnya, dalam berbagai aspek, pola sikap dan tingkah laku laki-laki dan perempuan terdapat perbedaan, termasuk dalam hal tingkah laku beragama (baca: ketaatan beragama). Jadi stereotip masyarakat tentang nilai anak laki-laki dan perempuan telah melahirkan perbedaan ketaatan beragama antara keduanya. Proses perbedaan ketaatan beragama antara anak laki-laki dan perempuan dapat digambarkan secara skematis sebagai berikut:

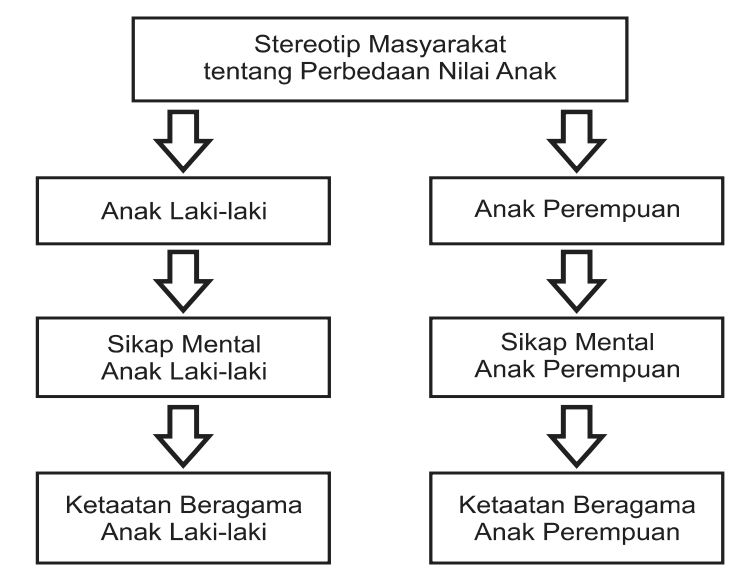

Skema 2.

Proses Terbentuknya Perbedaan Ketaatan Beragama

\section{Realitas Pendidikan Agama Islam}

Hipotesis inti penelitian ini adalah Pendidikan Agama berfungsi memprediksi ketaatan beragama. Secara rinci, penelitian ini akan menguji tiga hipotesis, yaitu (1) Pendidikan Agama berhubungan dengan ketaatan beragama siswa, (2) ketaatan beragama siswa dipengaruhi oleh lingkungan keagamaan siswa, (3) ketaatan beragama berhubungan dengan variabel jenis kelamin.

Hipotesis pertama menimbulkan asumsi bahwa siswa yang berhasil baik dalam Pendidikan Agama juga memiliki tingkat ketaatan beragama yang baik. Hubungan kedua variabel tersebut bersifat linier. Sedang hipoteisis kedua menunjukkan adanya peranan variabel lain, yaitu lingkungan keagamaan siswa, yang berpengaruh terhadap tingkat ketaatan beragama siswa. Hipotesis ketiga berasumsi bahwa antara siswa laki-laki dan siswa perempuan terdapat perbedaan ketaatan beragama. 
Berdasarkan uji statistik dalam korelasi tunggal antara variabel Pendidikan Agama dengan ketaatan beragama dihasilkan angka koefisien korelasi sebesar $0.1345<0.195$ pada $\propto 0.05$. Harga koefisien korelasi ini menunjukkan tidak ada korelasi yang signifikan antara Pendidikan Agama di SMA Negeri 1, SMA Negeri 6 dan SMA Negeri 8 Semarang tidak berhubungan yang berarti dengan ketaatan beragama siswa. Dengan demikian, Pendidikan Agama tidak mampu berfungsi memprediksi ketaatan beragama. Asumsi yang menyatakan bahwa siswa yang berhasil baik dalam Pendidikan Agama di sekolah cenderung memiliki ketaatan beragama yang tinggi tidak terbukti kebenarannya. Dengan kata lain, Pendidikan Agama tidak selalu mengindikasikan ketaatan beragama.

Mengapa fenomena tersebut dapat terjadi di SMA Negeri 1, SMA Negeri 6 dan SMA Negeri 8 Semarang? Menurut pengamatan penulis selama penelitian, ditemukan beberapa faktor yang diduga kuat menjadi penyebabnya, yaitu: (1) Pendidikan SMA yang berkiblat pada pengembangan akademis. Program sekolah lebih berorientasi formal pengajaran di kelas daripada pembinaan kepribadian (character building) secara menyeluruh. Lebih spesifik lagi, pendidikan di SMA memprioritaskan pengembangan mata pelajaran yang diUN-kan. (2) Sistem evaluasi Pendidikan Agama yang selama ini dilakukan lebih banyak bersifat verbal, sementara performance agama siswa tidak terjangkau evaluasi yang ada. Akibatnya, hasil Pendidikan Agama tidak mampu merefleksikan pengetahuan dan pengamalan agama sekaligus, melainkan hanya merefleksikan pengetahuan siswa tentang agama. (3) Pola pembinaan siswa tidak sistematis dan integral. Dalam pembinaan keagamaan siswa di luar jam belajar formal masih terbatas pada kegiatan ceremonial. Pembinaan yang bersifat terpadu dan sistematis masih sangat terbatas.

Fenomena tersebut sekaligus mengindikasikan adanya variabel lain yang berpengaruh terhadap ketaatan beragama siswa. Dalam penelitian ini ditemukan bahwa ketaatan beragama siswa ternyata berkorelasi positif secara signifikan dengan lingkungan keagamaan siswa. Dalam uji statistik ditemukan koefisien korelasi kedua variabel tersebut sebesar $0.209>0.195$ pada $\propto 0.05$. Hubungan tersebut bukan sebagai kebetulan karena kesalahan sampling, melainkan merupakan hubungan nyata. Berdasarkan korelasi parsial dan uji F dihasilkan harga F sebesar $4.43>3.94$ pada $\propto 0.05$.

Temuan ini bermakna bahwa lingkungan keagamaan siswa secara nyata berhubungan dengan ketaatan beragama siswa. Artinya, siswa-siswa yang memiliki lingkungan keagamaan baik cenderung taat beragama, dan sebaliknya 
siswa yang memiliki lingkungan keagamaan buruk cenderung kurang taat. Gejala ini sesungguhnya wajar sebab dalam lingkungan itulah siswa lebih banyak menghabiskan waktunya untuk belajar dari pada di sekolah. Di samping itu mereka juga dapat seacara langsung memperoleh pengalaman keagamaan dari lingkungan dan tidak dapat mereka peroleh di sekolah. Dengan demikian, maka lingkungan memberikan kontribusi yang lebih nyata terhadap terbentuknya ketaatan beragama dari pada sekolah.

Penelitian ini mengungkapkan pula bahwa variabel jenis kelamin ternyata tidak berperan dalam pembentukan ketaatan beragama. Dari hasil uji t ditemukan thasil observasi 0.22 yang berarti lebih kecil dari 2.01 pada $\propto 0.05$. Artinya, tidak ada perbedaan ketaatan beragama antara siswa laki-laki dan perempuan cenderung lebih taat ternyata tidak benar. Dalam kenyataannya, siswa laki-laki dan siswa perempuan memiliki ketaatan beragama yang relatif sama.

Gejala tersebut muncul sebagai konsekuensi dari perubahan-pertubahan yang terjadi dalam masyarakat. Menurut pengamatan penulis, masyarakat Kota Semarang sudah memiliki pola hidup yang modern. Pendidikan mereka relatif tinggi sehingga kemungkinannya mereka lebih rasional dan terbuka. Salah satu akibatnya stereotip tentang perbedaan laki-laki dan perempuan sudah memudar sehingga sikap dan perlakuan mereka terhadap laki-laki dan perempuan tidak lagi didasarkan atas suatu prasangka, melainkan berdasar prinsip rasional. Perbedaan laki-laki dan perempuan tetap ada. Perbedaan itu tidak bersifat normatif, tetapi kontekstual. Dengan demikian antara siswa lakilaki dan perempuan memiliki peluang yang relatif sama dalam berbagai aktivitas sehingga mereka memiliki kesempatan yang sama pula dalam membentuk sikap dan perilakunya, termasuk perilaku agama (ketaatan).

\section{Reorientasi Manajemen Pembelajaran PAI}

Tujuan Pendidikan Agama Islam adalah "untuk membimbing anak didik supaya menjadi Muslim sejati, beriman teguh, beramal shaleh, dan berakhlak mulia serta berguna bagi masyarakat, agama dan Negara". ${ }^{8}$ Menurut Mahmud Yunus dalam bukunya Metodik Khusus Pendidikan Agama, tujuan Pendidikan Agama dalam segala tingkat pengajaran adalah: (1) Menanamkan rasa cinta dan taat kepada Allah dalam hati anak-anak, yaitu dengan mengingatkan nikmat Allah yang tak terhitung banykanya. (2) Menanamkan i'tikad yang

${ }^{8}$ Alfian, Transformasi Sosial Budaya ..., h. 45 
benar dalam dada anak. Pendidikan anak-anak dari masa kecilnya supaya mengikuti suruhan Allah dan meninggalkan segala larangan-Nya, baik terhadap Allah maupun masyarakat, yaitu dengan mengisi hati mereka supaya merasa takut pada Allah dengan menginginkan pahala dan ridla-Nya. (3) Mendidik anak di masa kecil, supaya terbiasa dengan akhlak yang mulia dan adat kebiasaan yang baik. (4) Mengajar para pelajar supaya mengetahui faedah untuk mencapai kebahagiaan di dunia dan di akhirat. Begitu pula mengajarkan hukum-hukum agama yang perlu diketahui oleh tiap-tiap orang Islam serta mengikutinya. (5) Memberikan petunjuk kepada mereka sebagai bekal hidup di dunia dan mencapai kebahagiaan di akhirat. (6) Memberi suri tauladan yang baik, memberikan pengajaran dan nasihat. (7) Membentuk warga negara yang baik, berbudi luhur dan berakhlak mulia, serta berpegang teguh pada agama. ${ }^{9}$

Pendidikan yang kali pertama diberikan kepada anak adalah ketauhidan, keteladanan baik dalam melaksanakan ibadah atau pun tindakan serta ucapan dan nasihat agar kelak ia memiliki akhlakul karimah, bertanggungjawab dalam segala laku dan perbuatannya karena dilandasi dengan iman yang kuat serta tidak mudah terpengaruh.

Pendidikan Agama Islam mempunyai fungsi yang berbeda dengan subjek pelajaran yang lain. Oleh karena fungsi yang diemban terebut akan menentukan berbagai aspek pengajaran yang dipilih oleh pendidik agar tujuannya tercapai. Menurut John Sealy, sebagaimana dikutip oleh Ibnu Hadjar ${ }^{10}$ Pendidikan Agama (termasuk Pendidikan Agama Islam), dapat diarahkan untuk mengembangkan salah satu atau gabungan dari beberapa fungsi, yaitu konvensional, neo-konvensional, konvensional tersembunyi, implisit dan nonkonvensional. Fungsi-fungsi tersebut dapat dijelaskan sebagai berikut:

\section{Konvensional}

Menurut fungsi ini, Pendidikan Agama dimaksudkan untuk meningkatkan komitmen dan perilaku keberagamaan peserta didik. Dengan kata lain, Pendidikan Agama merupakan kepanjangan dari lembaga dakwah keagamaan sesuai dengan keyakinan yang dianut oleh peserta didik. Pendidikan Agama

\footnotetext{
${ }^{9}$ Mahmud Yunus, Metodik Khusus Pendidikan Agama, (Jakarta: Hidakarya Agung, 1983), h. 13

10Ibnu Hadjar, "Pendekatan Keberagaman dalam Pemilihan Metode Pengajaran Pendidikan Agama Islam," dalam Chabib Thoha, dkk. (ed.), Metodologi Pengajaran Agama, (Yogyakarta: Pustaka Pelajar), 1999.h. 7.
} 
dimaksudkan untuk mengagamakan orang yang beragama sesuai dengan keyakinannya. Fungsi ini didasarkan pada asumsi bahwa hanya ada satu kebenaran dalam beragama, yakni agama yang diyakini oleh masing-masing individu. Sekolah berfungsi membentuk peserta didik untuk mengembangkan serta meningkatkan keberagamaan siswa yang sudah dimilikinya sebelum masuk ke sekolah, sehingga tidak diperkenankan untuk memberikan alternatif lain kepada mereka.

\section{Neo-Konvensional}

Fungsi neo-konvensional, sebagaimana dalam fungsi konvensional, adalah untuk meningkatkan keberagamaan peserta didik sesuai dengan keyakinannya. Di samping itu, dalam fungsi ini juga diberikan kemungkinan keterbukaan untuk mempelajari dan mempermasalahkan ajaran agama lain. Namun demikian, pengenalan ajaran agama-agama lain tersebut adalah dalam rangka memperkokoh agama sendiri atau setidaknya hanya sekadar memahami keyakinan orang lain dalam rangka meningkatkan toleransi beragama di kalangan antar umat beragama. Untuk itu maka Pendidikan Agama agar tidak diberikan secara eksklusif, tetapi juga mencakup ajaran berbagai agama, meskipun sekedar perbanding.

\section{Konvensional Tersembunyi}

Dalam rangka mengemban fungsi ini, Pendidikan Agama menawarkan sejumlah pilihan ajaran agama dengan harapan peserta didik nantinya akan memilih salah satunya yang dianggap paling sesuai dengan dirinya, tanpa ada arahan pada salah satu di antaranya. Oleh karena itu ia harus memberikan ajaran berbagai agama secara fair dan mempersilahkan peserta didik untuk menerima atau menolak ajaran suatu agama. Fungsi ini di dasarkan pada asumsi bahwa manusia pada dasarnya adalah memiliki potensi beragama yang harus dikembangkan dan kebebasan untuk memilih.

\section{Implisit}

Fungsi ini dimaksudkan untuk mengenalkan kepada peserta didik ajaran agama secara terpadu dengan seluruh aspek kehidupan melalui berbagai subjek pelajaran. Karena itu, untuk mengemban fungsi ini tidak dikenal adanya subjek Pendidikan Agama secara mandiri. Fungsi ini lebih menekankan pada 
nilai-nilai universal dari ajaran agama yang berguna bagi kehidupan manusia dalam berbagai aspeknya. Dengan demikian, pengenalan nilai-nilai tersebut tidak dimaksudkan untuk memberikan warna agama pada berbagai aspek kehidupan, tetapi hanya sekedar untuk memberikan makna. Karena itu hanya nilai-nilai ajaran yang universal saja yang diberikan kepada peserta didik.

\section{Non-Konvensional}

Dalam fungsi ini, Pendidikan Agama dimaksudkan sebagai alat untuk memahami keyakinan atau pandangan hidup yang dianut oleh orang lain. Pendidikan agama tidak memiliki peran "agamis" tetapi semata-mata untuk mengembangkan sikap toleransi dalam rangka mengembangkan kerukunan antar umat manusia. Oleh karena itu Pendidikan Agama hanya difokuskan pada pengenalan tentang pengalaman kegamaan, tetapi bukan pengalaman itu sendiri sehingga tidak ada komitmen di dalamnya.

Undang-Undang No. 20 Tahun 2003, Pasal 3 menyebutkan, "Pendidikan nasional berfungsi mengembangkan kemampuan dan membentuk watak serta peradaban bangsa yang bermartabat dalam rangka mencerdaskan kehidupan bangsa, bertujuan untuk berkembangnya potensi peserta didik agar menjadi manusia yang beriman dan bertakwa kepada Tuhan Yang Maha Esa, berakhlak mulia, sehat, berilmu, cakap, kreatif, mandiri, dan menjadi warga negara yang demokratis serta bertanggung jawab". Oleh karena itu tidak semua fungsi tersebut sesuai dengan sistem pendidikan kita.

Dari penjelasan tersebut, paling tidak ada dua tujuan yang hendak dicapai dengan Pendidikan Agama, yakni meningkatkan keberagamaan peserta didik dan mengembangkan sikap kerukunan hidup antar umat beragama. Ini berarti fungsi yang sesuai adalah fungsi yang kedua, yakni neo-konvensional. Dengan fungsi ini Pendidikan Agama Islam diharapkan dapat mengantarkan peserta didik memiliki karakteristik "sosok manusia Muslim" yang diidealkan sekaligus memiliki sikap toleransi yang tinggi terhadap pemeluk agama lain.

Kendatipun demikian, dalam realitasnya, materi Pendidikan Agama Islam, sebagaimana juga materi Pendidikan Agama lainnya, lebih menekankan pada fungsi konvensional secara eksklusif tanpa sedikit pun mengenalkan ajaran agama lain. Tentu saja ini merupakan tantangan yang harus dijawab sesuai dengan undang-undang yang telah ditetapkan. 


\section{E. Deradikalisasi Agama}

Radikalisasi Agama berawal dari materi pelajaran yang diterima dan pemahaman terhadap isi materi. Oleh karena pemilihan materi pelajaran Pendidikan Agama Islam ikut menentukan terhadap pemikiran dan gerakan yang diperankan oleh peserta didik. Untuk mencapai tujuan pengajaran yang telah ditetapkan, maka materi yang akan disampaikan harus disesuaikan dengan tuntutan tujuan tersebut. Oeh karena itu penentuan materi pengajaran harus didasarkan pada tujuan, baik dari segi cakupan, tingkat kesulitan, maupun organisasinya. Dengan demikian, materi harus dapat mengantarkan peserta didik untuk bisa mewujudkan sosok individu sebagaimana yang digambarkan dalam tujuan. Secara garis besar, materi Pendidikan Agama Islam dapat dibedakan menjadi empat jenis, yaitu:

\section{Materi Dasar}

Materi Dasar yang dimaksudkan adalah materi yang penguasaannya menjadi kualifikasi lulusan dari pengajaran yang bersangkutan. Materi jenis ini diharapkan dapat secara langsung membantu terwujudnya sosok individu "berpendidikan" yang diidealkan, yakni mengantarkan peserta didik untuk mencapai sosok keberagamaan yang tercermin dalam dimensi-dimensinya (keyakinan, komitmen, ritual dan sosial). Di antara materi yang termasuk dalam jenis ini adalah; Tauhid (dimensi keyakinan), Fiqih (dimensi ritual dan sosial) dan Akhlaq (dimensi komitmen). Sedangkan untuk mengantarkan peserta didik agar memiliki sikap toleransi dengan pemeluk agama lain, maka perlu disampaikan materi tentang ajaran agama lain yang dipeluk dalam masyarakat (untuk mencapai pemahaman, bukan komitmen).

\section{Materi Sekuensial}

Materi Sekuensial yaitu materi yang dimaksudkan untuk dijadikan dasar untuk mengembangkan lebih lanjut materi dasar. Materi ini tidak secara langsung dan tersendiri akan mengantarkan peserta didik kepada peningkatan dimensi keberagamaan mereka, tetapi sebagai landasan untuk memperkokoh materi dasar. Di antara materi yang termasuk jenis ini adalah Tafsir dan Hadits, yang bertujuan agar peserta didik dapat memahami materi dasar dengan lebih baik. Demikian pula peserta didik perlu dikenalkan dengan kitab suci agama lain, meskipun hanya sekilas. 


\section{Materi Instrumental}

Materi Interumental yaitu materi yang tidak secara langsung berguna untuk meningkatkan keberagamaan, tetapi penguasaannya sangat membantu sebagai alat untuk mencapai penguasaan materi dasar keberagamaan. Adapun yang tergolong materi ini, dalam pendidikan Agama Islam adalah Bahasa Arab. Karena sebagian besar sumber ajaran Islam seperti al-Qur'an, Hadits, dan kitabkitab adalah berbahasa Arab, maka penguasaan terhadap Bahasa Arab mutlak diperlukan.

\section{Materi Pengembangan Personal}

Materi Pengembangan Personal yaitu materi yang tidak secara langsung meningkatkan keberagamaan ataupun toleransi beragama, namun mampu membentuk kepribadian yang sangat diperlukan dalam "kehidupan beragama". Di antara materi yang termasuk dalam kategori jenis ini adalah sejarah kehidupan manusia, sejarah Rasul, sejarah Islam. Dari sejarah kehidupan, peserta didik dapat memahami apa yang dapat menyebabkan terjadinya "corak kehidupan" tertentu, baik yang menguntungkan maupun yang merugikan sehingga menjadi pelajaran yang sangat berharga bagi mereka. Suatu pelajaran untuk meniru yang baik dan meninggalkan yang tidak baik.

Pemakaian metode yang tepat sangat membantu keberhasilan materi yang akan disampaikan. Metode harus dipilih sesuai dengan materi yang akan diajarkan. Karena tidak ada suatu metode yang paling baik untuk semua materi, maka pemakaian metode harus disesuaikan dengan materi masing-masing.

Selama ini penyampaian materi Pendidikan Agama Islam lebih banyak menggunakan metode ceramah dan hafalan. Dua metode ini hampir selalu dipakai untuk menyampaikan semua materi PAI. Padahal tidak semua materi PAI cocok dan memenuhi sasaran hanya dengan dua metode tersebut. Bukan berarti kedua metode tersebut tidak baik, akan tetapi perlu diselingi atau dikombinasi dengan metode yang lain. Metode tersebut antara lain adalah metode sosiodrama, karyawisata, inquari, latihan, diskusi dan sebagainya.

Beberapa alternatif pemakaian metode tersebut disamping untuk mencapai sasaran yang tepat, juga untuk mengurangi kejenuhan pada diri peserta didik. Perlu diingat bahwa Pendidikan Agama Islam terdapat dalam semua jenjang pendidikan, sejak pendidikan dasar sampai perguruan tinggi. Ini berarti akan terjadi pengulangan-pengulangan yang menyebakan pada kebosanan. 
Oleh karena itu kesan yang timbul kemudian adalah 'menyepelekan' terhadap Pendidikan Agama. Karena di samping materinya hanya berupa ulanganulangan, juga metode yang disampaikan tidak menarik.

Apabila ditinjau dari ranah pengajaran yang ingin dituju, maka Pendidikan Agama Islam juga harus mencapai sasaran kognitif, afektif dan psikomotorik. Untuk mencapai sasaran kognitif mungkin cukup dengan metode ceramah, diskusi dan hafalan. Akan tetapi untuk mencapai sasaran afektif dan psikomotorik, maka alangkah lebih baik jika metode yang diterapkan adalah sosiodrama, karyawisata, bakti sosial dan sebagainya. Dengan metode-metode semacam ini, peserta didik akan terlibat langsung dengan pengalaman nyata dalam kehidupannya. Dengan demikian, maka secara tidak langsung, peserta didik akan dibawa kepada pola pendekatan emosional dan praktikal.

Pemilihan beberapa metode tersebut sangat bermanfaat untuk menunjang keberhasilan belajar peserta didik Selama ini yang sering menjadi sorotan bahwa kelemahan pembelajaran agama Islam di Indonesia adalah terletak pada pemakaian metode yang monoton pada ceramah dan hafalan saja. Sehingga siswa merasa bahwa Pendidikan Agama hanya berfungsi pada dataran kognitif saja. Padahal disamping target penguasaan materi keagamaan yang ingin dituju dalam Pendidikan Agama Islam adalah aspek keyakinan, komitmen keagamaan, ritual dan aspek sosial sekaligus.

Dari uraian di atas, maka sudah saatnya, untuk menyampaikan materi Pendidikan Agama Islam diperlukan guru yang profesional, bukan hanya dalam ilmu-ilmu keislaman, tetapi juga profesional dalam bidang kependidikan dan betul-betul memiliki komitmen keislaman. Dengan sumber daya manusia yang demikian, diharapkan Pendidikan Agama Islam bukan hanya sebagai 'pelengkap penderita' yang hampir dipastikan setiap siswa pasti akan lulus dalam mata pelajaran ini, walaupun nilai riilnya kurang dari enam.

\section{F. Kesimpulan}

Dari pembahasan tersebut, penulis menyampaikan beberapa kesimpulan dan saran-saran sebagai berikut: (1) Pendidikan agama di SMA Negeri Kota Semarang cenderung hanya mengambarkan pengetahuan agama siswa, dan tidak berfungsi memprediksikan tingkatan ketaatan beragama siswa. (2) Tingkat ketaatan beragama siswa berhubungan searah dengan lingkungan keagamaan siswa, artinya lingkungan keagamaan siswa memiliki konstribusi 
yang besar dan nyata terhadap ketaatan beragama. (3) Tingkat ketaatan beragama siswa tidak dipengaruhi oleh variabel jenis kelamin, artinya siswa laki-laki memiliki tingkat ketaatan beragama yang relatif sama dengan siswa perempuan. (4) Reorientasi manajemen Pendidikan Agama Islam, ke fungsi neo-konvensional. Dengan fungsi ini Pendidikan Agama Islam diharapkan dapat mengantarkan peserta didik memiliki karakteristik "sosok manusia Muslim" yang diidealkan sekaligus memiliki sikap toleransi yang tinggi terhadap pemeluk agama lain, dan (5) Deradikalisasi Pendidikan Agama Islam dapat ditanggulangi mulai dari pemilihan materi ajar yang diberikan kepada anak didik. Materi ajar meliputi materi dasar, materi sekuensial, materi instrumental, dan materi pengembangan personal,

Berdasarkan kesimpulan di atas, maka penulis menyampaikan saran-saran sebagai berikut: (1) Orientasi pendidikan hendaknya terpadu sehingga verbalisme dapat dihindari dan Pendidikan Agama menjadi fungsional. (2) Proses Pendidikan Agama dan sistem evaluasinya perlu diarahkan pada pola pembinaan yang komprehenship, meliputi seluruh kawasan pengetahuan dan bersifat terpadu. (3) Sekolah hendaknya mengembangkan pola pembinaan agama siswa secara sistematis dan terpadu dengan mengikutsertakan semua guru, orang tua siswa, masyarakat dan siswa, sehingga tercipta lingkungan agama yang kondusif bagi terbentuknya ketaatan beragama siswa. (4) Orientasi Pendidikan Agama harus di arahkan kepada pembentukan pribadi Muslim baik, dan sekaligus Muslim yang memiliki toleransi terhadap pemeluk agama lain dan pemeluk Islam yang berfaham lain.

Dengan demikian, keberhasilan Pendidikan Agama adalah tanggung jawab semua pihak, baik guru agama (sekolah), orang tua, dan masyarakat (lingkungan). Oleh karena itu kerjasama antar ketiga komponen tersebut harus terbina dengan baik. Tanpa kerjasama yang baik antar komponen-komponen ini, maka keberhasilan Pendidikan Agama tidak akan dapat optimal antara aspek kognitif, afektif dan psikomotor. Oleh karena itu masing-masing komponen harus dapat memerankan diri sebagaimana fungsinya, misalnya Pendidikan Agama di sekolah lebih mengarah ke aspek kognitif, sementara Pendidikan Agama di dalam keluarga dan masyarakat lebih menekankan pada aspek afektif dan psikomotor.[w] 


\section{BIBLIOGRAFI}

Alfian, Transformasi Sosial Budaya dalam Pembangunan Nasional, Jakarta; UI Press, 1985.

Ariviva, Gadis, "Feminisme Pasca Modernis", Jurnal Prisma, Nomor 1, 1993.

Buchori, Mochtar, "Transformasi Tata Nilai”, dalam Himpunan Prasarana dalam Seminar Polri, Jakarta: PTIK, 1991.

Budiman, Arif, Pembagian Kerja Secara Seksual; Sebuah Pembahasan Sosiologis tentang Peran Wanita di dalam Masyarakat, Jakarta: Gramedia, 1985.

Daradjat, Zakiah, Pendidikan dalam Keluarga dan Sekolah, Jakarta: Rohana, 1993.

Daradjat, Zakiah, Peranan Agama dalam Kesehatan Mental, Jakarta: Haji Masagung, 1988.

Hadi, Sutrisno, Statistik, Yogyakarta: Andi Offset, 1991.

Hadjar, Ibnu, "Pendekatan Keberagaman dalam Pemilihan Metode Pengajaran Pendidikan Agama Islam," dalam Chabib Thoha, dkk. (ed.), Metodologi Pengajaran Agama, Yogyakarta: Pustaka Pelajar, 1999.

al-Ibrashi, Muhammad Atiya, Education in Islam, Cairo: The Supreme Council for Islamic Affairs, 1967.

John W. Best, Research in Education, Englewood Cliffs, NJ: Prentice Hall, INC, 1981.

Langgulung, Hasan, Pendidikan Islam Mengahadapi Abad ke- 21, Jakarta: Pustaka al-Husan, 1988.

al-Nahlawi, Abdurrahman, Prinsip-prinsip dan Metoda Pendidikan Islam, Dalam Keluarga di Sekolah dan di Masyarakat, Bandung: Diponegoro, 1989.

Syafif, MM., Islamic and Educational Studies, Lahore: Institute of Islamic Culture, 1964.

Satmoko, Setno Sariningsih, Statistik Inferensial, Semarang: IKIP Semarang, 1993.

Thoha, Chabib, Kapita Selekta Pendidikan Islam, Yogyakarta: Pustaka Pelajar, 1996.

Wirawan, Sarwono dan Heri Susianti, "Upaya Penegakan Disiplin Nasional dalam Kerangka Nilai-nilai Sosial Budaya Indonesia: Suatu Analisis Psikososial," dalam Himpunan Prasaran dalam Seminar Polri, Jakarta: PTIK, 1991. 